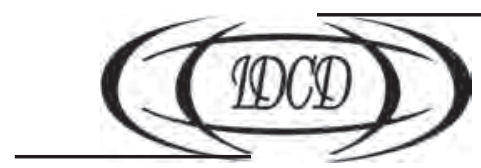

doi: $10.15407 /$ dse2016.02.026

УДК 314.146

JEL Classification: J120, J130

\title{
Л.І. СЛЮСАР
}

канд. екон. наук, пров. наук. співроб.

Інститут демографії та соціальних досліджень

ім. М.В. Птухи НАН України

01032, Україна, Київ-32, бул. Тараса Шевченка, 60

E-mail: L.Slyusar@bigmir.net

\section{БАТЬКІВСТВО У СИСТЕМІ ВІДНОСИН ІНСТИТУТУ СІМ'Ї: СУЧАСНІ ТРАНСФОРМАЦЇ̈, ЇХ ПРИЧИНИ ТА НАСЛІДКИ}

Сім'я як багатофункціональний комплексний соціальний інститут має складну внутрішню структуру, однак саме механізми-відносини батьківства забезпечують реалізацію основнихї̈ функцій - народження, утримання, соціалізація дитини. Наслідком сучасних трансформацій інституту сім'ї, різноманіття типів і форм сімейних об'єднань стала значна специфіка батьківства в різних сім'ях, плюралізація його форм. Специфіку виконання функцій батьківства мають сім'ї, які відрізняються за типом поселення (міські та сільські), за кількістю дітей (багатодітні та однодітні), за структурою сім'ї (прості й складні багатопоколінні). Принципово змінена форма батьківства у сім'ях, які з'явились внаслідок сучасної модернізації шлюбно-сімейної поведінки населення: однобатьківські сім'ї, реструктуровані сім'ї, сім'ї з дистанційним шлюбом. Треба визнати наявність певних протиріч міжк свободою вибору стилю життя, плюралізацією форм шлюбу і сім'ї, і потребою суспільства у комфортних умовах соціалізації підростаючого покоління, які забезпечує традиційний інститут батьківства. Розв'язання цього протиріччя потребує не повернення до старих форм шлюбно-сімейної поведінки, що неможливо, а модернізації інституту батьківства на сучасних гуманістичних принципах поваги і любові до кожноі дитини, відповідального ставлення до неї незалежно від форми шлюбних стосунків батьків, тобто на принципах відповідального батьківства.

В Україні поширення бідності серед сімей з дітьми, невирішеність житлової проблеми, алкоголізм та наркоманія серед частини населення впливають на систему відносин батьки-діти, деформуючи специфіку батьківства у різних типах сім'ї, посилюючи негативні моменти та збільшуючи ризики, які продукує плюралізація форм батьківства. Складність сучасного етапу розвитку України, в першу чергу через збройний конфлікт на сході крайни, посилює ці ризики та формує нові виклики.

Ключові слова: сім'я, батьківство, діти, илюб, суспільство, інститут, відповідальне батьківство.

\section{Л.И. Слюсар}

канд. экон. наук, вед. науч. сотруд.

Институт демографии

и социальных исследований им. М.В. Птухи НАН Украины

01032, Украина, Киев-32, бул. Тараса Шевченко, 60

E-mail: L.Slyusar@bigmir.net

(С) СЛЮСАР Л.І., 2016 


\section{РОДИТЕЛЬСТВО В СИСТЕМЕ ОТНОШЕНИЙ ИНСТИТУТА СЕМЬИ: СОВРЕМЕННЫЕ ТРАНСФОРМАЦИИ, ИХ ПРИЧИНЫ И ПОСЛЕДСТВИЯ}

Семья как многофункциональный комплексный социальный институт имеет сложную внутреннюю структуру, но именно механизмы-отношения родительства обеспечивают реализацию основных ее функций - рождение, содержание, социализация ребенка. В результате современной трансформации института семьи, многообразия типов и форм семейных объединений, возникли значительные различия в выполнении функций родительства в разных семьях, т. е. плюрализация форм родительства. Специфику родительства имеют семьи, отличающиеся по типу поселения (городские и сельские), по количеству детей (многодетные и однодетные), структурой семьи (простые и сложные -многопоколенные). Принципиально изменена форма родительства в семьях, которые появились в результате современной модернизации брачно-семейного поведения населения: в однородительских семьях, реструктурированных семьях, семьях с дистанционным браком. Следует признать существование определенных противоречий между свободой выбора стиля жизни, плюрализацией форм брака и семьи, и потребностью общества в комфортных условиях социализации подрастающего поколения, которые обеспечивает традиционный институт родительства. Разрешение этого противоречия возможсно не путем возврата к старым формам брачно-семейного поведения, что нереально, а модернизацией института родительства на современных гуманных принципах уважения и любви к каждому ребенку, ответственного отношения $\kappa$ нему независимо от формы брачных отношений родителей, то есть на принципах ответственного родительства.

В Украине бедность семей с детьми, нерешенность жилищной проблемы, алкоголизм и наркомания среди части населения влияют на систему отношений родители-дети, деформируя специфику родительства в разных типах семей, усиливая негативные моменты и увеличивая риски, которые продуцирует плюрализация форм родительства. Сложсность современного этапа развития Украины, в первую очередь из-за военного конфликта на востоке страны, усиливает эти риски и формирует новые вызовы.

Ключевые слова: семья, родительство, дети, брак, общество, институт, ответственное родительство.

\section{L.I. Slyusar}

Ph. D., Leading scientific worker

Ptoukha Institute for Demography and Social Studies

National Academy of Sciences of Ukraine

01032, Ukraine, Kyiv-32, Taras Shevchenko Blvd., 60

E-mail: L.Slyusar@bigmir.net

\section{PARENTHOOD IN THE SYSTEM OF RELATIONS OF FAMILY INSTITUTE: MODERN TRANSFORMATIONS, THEIR CAUSES AND CONSEQUENCES}

The family as a multifunctional social institution has a complex internal structure, but the mechanisms of parenting relationship provide the realization of main family functions - birth, maintenance, socialization of the child. Specificity of parenthood in different families and pluralization of parenting forms are the consequence of the modern transformation of the family and different types of family associations. The parenting functions and relationships are diverse in families of different settlement type (urban and rural), with different number of children (multi-child and one-child family), and structure (simple and complex). But form of parenthood is fundamentally changed in families that emerged as a result of modernization of marriage and family behavior of the population: family with single parent, restructured family, a family with long-distance marriage. There are certain contradictions between freedom of choice of lifestyle that pluralization of forms of marriage and family provides, and social demand for the "comfortable" conditions of socialization of the younger generation, which traditional institution of parenthood provides. Resolving these contradictions doesn't require return to the previous forms of marriage and family behavior that is impossible; but it requires modernization of the institution of parenthood based on the modern humanist principles of respect and love for each child, understanding of the value of them, responsible attitude to them irrespective of the forms of marital relationship of parents.

In Ukraine the expansion of poverty among families with children, unresolved housing problems, alcoholism, and drug addiction affect the system of relationship between parents and children. These problems deform 
the specificity of parenthood in different types of families, intensify negative aspects, and increase the risks. The complexity of the current stage of development in Ukraine, primarily due to the military conflict, increases those risks and creates new problems.

Key words: family, parenthood, children, marriage, society, institute, responsible parenthood.

Постановка проблеми. На рубежі тисячоліть, коли людство перебуває на принципово новому етапі розвитку, заснованому на постіндустріальних засадах соціальної та технологічної організації, відбувається кардинальна трансформація суспільних інститутів, у тому числі інституту сім’ї. Сім’я є багатоаспектним соціальним утворенням, яке поєднує в собі якості соціального інституту, соціальної організації, соціальної структури та малої соціальної групи [1, С. 22]. Дослідження сім’ї на макрорівні як соціального інституту розкриває їі взаємозв'язок із іншими соціальними інститутами та соціально-демографічними процесами, що є підгрунтям для розуміння причин іiі сучасних трансформацій.

Сім'я як багатофункціональний соціальний інститут має складну внутрішню інституційну архітектоніку, яка може бути представлена у вигляді сукупності внутрішніх системно-структурних інститутів та їх взаємовідносин і взаємозв’язків ${ }^{1}$. На нашу думку, сім'я як комплексний інститут об'єднує інститути шлюбу, батьківства і спорідненості (родства). Кожен із цих інститутів має значну інституціональну автономію, регулює правила, механізми, норми поведінки у певній сфері, тому розуміння змін сім'ї як основного осередку відтворення населення потребує як всебічного дослідження кожного з цих інститутів, так і їх взаємодії.

Динамічність і неоднозначність сучасних процесів у сімейній сфері обумовлюють необхідність більшої уваги дослідників до трансформації не тільки сім’ї у комплексі всіх залежностей-взаємодій ії відносин, але і поглибленого дослідження кожного з іiі складових-інститутів. Традиційними є дослідження шлюбу як окремого соціального інституту (А. Волков (А. Volkov), Л. Чуйко (L. Chuiko), А. Харчев (A. Kharchev)), однак батьківство і спорідненість у цьому ключі розглядаються вкрай рідко. Батьківство, як і сім’я вцілому, є об’єктом вивчення різних наук, однак у більшості випадків демографи досліджують дітородні орієнтації населення та їхній вплив на дітність сім’ї, тобто кількісні характеристики батьківства та механізми їх формування [3]. Батьківство досить часто є об’єктом досліджень психологів і педагогів у площині виховного процесу [4], однак є лише окремі спроби вивчення батьківства як соціального інституту Т. Гурко (T. Gurko) [5]. На нашу думку, вкрай важливим є вивчення батьківства як складової інституту сім’ї у контексті відтворення населення. Аналіз батьківства як складової інституту сім’і, його сучасних трансформацій та зумовлених ним викликів, у тому числі сучасних особливостей батьківства в Україні, є метою цієї статті.

Виклад основного матеріалу. Батьківство - це історично обумовлена соціальна форма відносин, що соціально санкціонує і впорядковує фізичний (біологічний) процес продовження роду людської спільноти. Інститут батьківства упорядковує стосунки між батьками і дітьми, батьками і суспільством, визначаючи в першу чергу права і обов'язки батьків з утримання і виховання дітей.

Дослідження батьківства неможливо без дослідження сім’і, його місця у системі сімейних відносин. Сім'я як комплексний інститут об'єднує інститут шлюбу, інститут батьківства і інститут спорідненості. Шлюб - це інститут, який регулює взаємовідносини між чоловіком і жінкою, визначає їхні права і обов’язки стосовно

\footnotetext{
${ }^{1}$ Про архітектоніку як науку, у тому числі про інституціональну архітектоніку, див. [2].
} 
один одного та їх дітей, за визначенням В. Медкова (V. Medkov) [1, С. 291]. Інститут батьківства формує відносини між батьками та дітьми, визначаючи форми і правила їхньої взаємодії. Інститут спорідненості визначає форми взаємовідносин між іншими кровними родичами, тобто братами і сестрами, прабатьками і онуками тощо. Кожен із цих інститутів регулює правила, механізми, норми поведінки у певній сфері, однак саме їх поєднання забезпечує виконання всього комплексу функцій сім'ї, робить її базовим осередком суспільства. Взаємозалежність і взаємозацікавленість батьків і дітей, шлюбних партнерів, родичів, формальні і неформальні механізми і правила їхньої взаємодії обумовлюють фундаментальну якість сім’ї - виконання ролі посередника між суспільством і особистістю через інтереси сім'ї стосовно фізичного і соціально-культурного відтворення населення [1, С. 22].

Хоча більшість вітчизняних та зарубіжних дослідників вважають основою (ядром) сім'ї шлюб (А. Волков, Л. Чуйко), варто зазначити, що найважливіші - специфічні функції сім'ї: народження, виховання і утримання дітей, - реалізуються через батьківство. Саме механізми-відносини батьківства забезпечують народження, розвиток, соціалізацію дитини, i саме тому сім'я є первинним осередком відтворення населення, основним осередком фізичного і соціокультурного відтворення поколінь людського співтовариства. На першочергове значення саме батьківства для сім'ї звертали увагу такі відомі соціологи як Роберт Нисбет (R. Nisbet), Карл Циммерман (C. Zimmerman), А. Антонов (A. Antonov) [1, C. 44; 6].

Механізми-відносини батьківства функціонують через гендерні механізми, ієрархію прав і обов'язків матері та батька, рівновагу їх сімейних ролей. Обмін діяльністю чоловіком та жінкою для забезпечення умов розвитку дитини є необхідною умовою реалізації функцій батьківства.

Батьківство, як і інститут сім'ї загалом, є поєднанням формальних і неформальних норм і правил стосунків між батьками і дітьми. Неформальні норми та правила батьківства, які регулюють його психологічні, емоціональні, ряд фізичних аспектів, є особливо важливими, оскільки грунтуються на природному компоненті фізичної й емоціональної взаємозалежності та взаємодії батьків і нащадків, наявному у певній формі у всіх високорозвинених представників природного світу. Разом 3 тим ці «природні» стосунки у людини набувають соціальної форми, що залежить від традицій даної спільноти, системи життєвих цінностей, поширених моральноетичних принципів та орієнтацій. Шодо формальних норм і правил, то з розвитком людства вони змінювались від інфантициду в архаїчних спільнотах з їх обмеженістю ресурсів, та байдужістю до маленьких дітей у доіндустріальний період із його високою дитячою смертністю (I. Кон (I. Kon)) [7, С. 39-65], до сучасного дітоцентризму суспільства (принаймні, декларованого). Якщо використовувати поняття гаранта [2, С. 45], то гарантом дотримання формальних норм і правил батьківства на різних етапах історичного розвитку були громада, церква, держава. У наш час ці формальні правила закріплені у законодавчих актах і документах. В Україні права і обов'язки батьків щодо виховання і утримання дитини закріплені у Сімейному кодексі (розд. III «Права та обов'язки матері, батька і дитини»). Там же визначені санкції держави у випадку невиконання батьками своїх обов'язків (позбавлення батьківських прав тощо), а також вікові межі дитинства.

Сім'я як базовий інститут суспільства характеризується значною стабільністю і жорстко не залежить від соціально-економічної моделі соціуму, однак вона поступово змінюється відповідно до внутрішньої логіки свого розвитку. Водночас ці ії зміни 
«вплетені» у тканину історичного розвитку всього суспільства. Як відтворення населення відбувається у всьому просторі суспільно-економічного життя, є властивістю суспільного життя загалом [8, С. 466], так і функціонування сім’ї як первинного осередку відтворення нових поколінь відбувається у соціально-економічному просторі, є взаємозалежним зі всіма сферами життєдіяльності соціуму, є органічною складовою інституційного середовища, знаходиться під впливом цього середовища та його складових - конкретних інститутів.

Трансформація сім’ї є наслідком і складовою якісних змін усього соціуму, переходу спочатку до індустріальної, а потім до постіндустріальної (інформаційної) його моделі. Потребам доіндустріального (аграрного) суспільства відповідала велика багатодітна сім'я, де разом мешкали не тільки батьки і діти, але і представники старшого покоління, брати і сестри, що було обумовлено сімейним характером виробництва, високою смертністю населення, низькою продуктивністю праці. На цьому етапі розвитку інститут сім’ї мав монолітну, чітко визначену внутрішню архітектоніку, його складові щільно поєднані, переплетені: шлюб є обов’язковою передумовою батьківства, велика кількість дітей є запорукою розгалуженої системи відносин спорідненості між братами і сестрами. Неодмінним атрибутом батьківства була багатодітність, відсутність сімейних механізмів обмеження дітонародження.

3 розвитком суспільства, підвищенням продуктивності праці та зниженням смертності, великий розмір сім’ї вже не є обов’язковою запорукою ії матеріального добробуту, а висока народжуваність - запорукою виживання людства. Інституціональна структура суспільства поступово ускладнюється, і окремі функції сім'ї переходять (частково чи повністю) до інших інститутів. У ході історичної еволюції сім’ї інститути шлюбу, батьківства і спорідненості не тільки зазнають значних трансформацій, змінюються і форми їх взаємодії, збільшується автономність, ускладнюється система взаємозв’язків.

Відправною точкою змін інституту сім’ї стало зниження народжуваності в умовах формування нового типу демографічної рівноваги. Зниження дитячої смертності створило передумови для обмеження сім'єю кількості дітонароджень, що не тільки вплинуло на розмір сім’ї, зменшило їі дітність, але і вплинуло на весь комплекс взаємовідносин батьки-діти, поступово формуючи нову якість. 3’явились умови для перебудови всього комплексу зв’язків-відносин сім’і, у тому числі інститутів шлюбу та спорідненості.

Зміни кількісних характеристик батьківства стали пусковим механізмом перебудови інституту спорідненості, звуження його функцій: перехід від багатодітної до малодітної, а особливо однодітної сім'ї значно звужує, обмежує цей інститут за рахунок зменшення кількості братів і сестер. Змінює форми родинних зв'язків і процес нуклеарізації сім’ї, формуючи нові форми взаємодії батьків і дорослих дітей.

Сучасна модель народжуваності стала як причиною, так і наслідком змін у системі взаємозв’язків шлюбу і батьківства. У другій половині XX сторіччя досить міцний і прямий зв'язок цих інститутів змінюється, їх взаємообумовленість набуває іншої, непрямої та досить неоднозначної форми. Норми і правила, які забезпечували пряму залежність дітонародження від офіційно визнаного шлюбу чоловіка і жінки, поступово розмиваються: інститут шлюбу і інститут батьківства набувають значної автономії, їх зв'язок стає більш складним і глибинним. Зміни у формах взаємодії шлюбу та батьківства є значною мірою результатом трансформації характеристикознак інституту шлюбу: це підвищення віку вступу до шлюбу, відхід від «шлюбу на все життя», плюралізація форм шлюбу. Якщо підвищення віку вступу до шлюбу змінює 
одну із зовнішніх його характеристик, то нестабільність шлюбних відносин, коли перебування у шлюбі не обмежує потенційну можливість людини до вступу у новий шлюб; дистанційний і гостьовий шлюб, коли зникає спільне проживання подружжя, та розмитість меж шлюбу у випадку його нереєстрації, - є свідченням глибинної перебудови норм і правил, які регулюють шлюбні стосунки. Ці зміни визначають як другий демографічний перехід (Second Demographic Transition) [9].

Основними причинами, які продукують зміни відносин-зв'язків інституту сім'ї, у тому числі інституту батьківства у його кількісному і якісному вимірі, є: розвиток системи матеріального виробництва, його інтенсифікація; зміни у системі розподільчих відносин; ускладнення інституційної структури соціуму; зростання мобільності населення; перебудова системи гендерних відносин на принципах емансипації; широке розповсюдження контрацепції; сексуальна революція; гнучкість сучасних соціальних і моральних норм і правил; поширення принципів свободи вибору.

Розвиток економіки потребує праці членів сім’ї, чоловіків і жінок, у різних галузях суспільного виробництва, а зі зростанням темпів модернізації ринок праці та освітніх послуг продукує значну мобільність населення, змінюючи форму сімейних зв’язків, територіально роз'єднуючи не тільки дорослих дітей та їхніх батьків, братів і сестер, але в певних випадках і подружні пари, одного з батьків і дітей. Принципово змінилось становище жінки у суспільстві. Економічно і соціально незалежна жінка стає більш самостійною у шлюбі, у виборі моделі дітородної поведінки; вона не залежить економічно від чоловіка, адже стабільність шлюбу вже не є обов'язковою запорукою їі добробуту.

Вагомим фактором трансформації сім’ї є роз'єднаність репродуктивної, шлюбної та сексуальної поведінки, їх сучасна автономність [10, С. 130-137]. Планування дітонародження (як за кількістю дітей, так і за часом їх появи на світ), яке стало особливо надійним завдяки досягненням сучасної контрацепції, не тільки сприяло зниженню дітності сім'ї, але й створило умови для нестабільності шлюбу, зростання кількості розлучень. Гнучкість сучасних моральних і соціальних норм, терпимість до різних форм сексуальної та шлюбно-сімейної поведінки сприяють подальшій плюралізації форм шлюбу та сім’ї.

Існують різні погляди на сучасні зміни інституту сім'ї та шлюбу та на їх наслідки, і критерієм оцінки цих змін є їхній вплив на виконання сім'єю функцій щодо утримання і соціалізації дітей, на систему відносин батьки-діти. Модернізація інституту шлюбу (різноманіття його форм, нестійкість шлюбу, висока вірогідність повторного шлюбу, нова форма взаємозв'язку шлюбу і дітонародження) призвела до поширення нових типів шлюбно-сімейних об'єднань, які раніше виникали внаслідок дії зовнішніх негативних факторів (війни, висока смертність), а не свідомого вибору особистості, і вважались винятком із правил, - це однобатьківські сім’ї, реструктуровані сім'ї, сім'їз дистанційним шлюбом. Умови реалізації функцій батьківства в цих типах сімей мають значну специфіку, суттєво відрізняються від традиційної сім'ї з батьком і матір'ю, породжують численні проблеми та неоднозначні оцінки. Поширеність цих типів сімей із дітьми дає підстави говорити про різноманітність, плюралізацію форм батьківства у сучасному світі.

Треба визнати, що різноманіття типів, розміру, структури сімейних об’єднань завжди формує певні відмінності в умовах розвитку дитини, особливості у системі стосунків батьки-діти. Певні відмінності у виконанні функцій батьківства мають міські та сільські сім’ї, багатодітні та однодітні сім’ї, прості й складні (багатопоколінні) сім’ї, сім’ї, в яких батьки мають різний рівень освіти, соціальний та професійний статус тощо. 
Наприклад, сільські і міські сім’ї відрізняються не тільки побутом дітей і дорослих, сільські діти більш залучені до спільної з дорослими праці, мають ширше коло сімейних обов'язків, їхня соціалізація відбувається значною мірою через участь у загальносімейній трудовій діяльності. Існує думка, що загальносімейна діяльність $є$ неодмінною умовою повноцінної соціалізації дитини в сім’ї [1, С. 229, 240-241].

Мають певну специфіку багатодітні сім’ї, особливо у порівнянні з однодітними: у цих сім'ях існує ризик недостатньої уваги батьків до кожній дитині, неможливість врахувати всі її особливості. Але у випадку, коли багатодітність є свідомим вибором подружжя і всі діти є бажаними, у такій сім’і більше можливостей створити атмосферу взаємної турботи і поваги, виховати у дітей відповідальність, контактність, працелюбство, здатність до співчуття, унеможливити їхню самотність у майбутньому.

Структура сімейного об'єднання також впливає на виконання батьківських функцій. У складних, багатопоколінних сім’ях (частка яких у загальній кількості сімей з дітьми поступово зменшується) представники старшого покоління беруть безпосередню участь у організації життєдіяльності і вихованні дітей, що впливає на систему відносин батьки-діти трьох поколінь. Сімейні ролі бабусі і дідуся є важливими для родини: беручи участь у домашній праці та вихованні онуків вони сприяють і створенню комфортних умов для розвитку дітей, і можливості для батьків поєднувати професійні й сімейні обов'язки. Разом з тим, різниця у поглядах і стилі життя представників різних поколінь можуть стати підгрунтям сімейних конфліктів, особливо коли їх об’єднання у одному домогосподарстві є вимушеним. Однак не можна не згадати, що низка вчених-фамілістів вважають найбільш привабливою формою сім'ї, яка може в повному обсязі виконувати всі функції цього інституту, сім'ю, в якій є весь комплекс подружніх-батьківських-родинних відносин, і ці погляди базуються на концепції «корнєвої сім’'̈» Фредеріка Ле Пле (F. Le Play) [11], тобто батьківська сім’я плюс репродуктивна сім'я з кількома дітьми (як правило, старшого сина) з певною системою внутрішньосімейних і економічних відносин [1, С. 93-94, 12, с. 16].

Однак за всіх відмінностей перерахованих вище форм і типів сімей принципи виконання батьківських функцій у них по суті є традиційними - дітей утримують і виховують рідні батько і мати, які мешкають в одному домогосподарстві. Принципові відмінності форм і правил батьківства ми спостерігаємо у сімейних об'єднаннях, які з'явились внаслідок поширення сучасних особливостей шлюбно-сімейної поведінки населення: однобатьківські та реструктуровані сім’ї, сім’ї з дистанційним шлюбом. Батьківські обов'язки в цих сім'ях виконує фактично один із батьків (як правило мати), чи не рідний батько/мати, або батьківські функції виконуються «на відстані». Оскільки традиційне середовище виховання дитини в цих випадках принципово змінено / деформовано, існують багато критичних оцінок цих форм батьківства А. Антонов, А. Карлсон (А. Antonov, A. Carlson). Разом з тим дослідники, які вивчають становище дітей у цих сім'ях, іноді доходять різних висновків. Так, Елізабет Томсон і Сара Макланахан (Elizabeth Thomson and Sara McLanahan) на основі лонгітюдного дослідження становища дітей у сім'ях різних типів дійшли висновку про несприятливі умови розвитку дитини у всіх «альтернативних» формах сім'ї (незареєстрований шлюб рідних батьків, нерідний батько, однобатьківська сім'я), особливо несприятливими на думку цих дослідників є умови проживання дітей у сім'ях, де їх виховує мати та вітчим, шлюб яких офіційно не зареєстрований [13]. Потри це існує думка, що однобатьківські та реструктуровані сім’ї мають достатній потенціал для повноцінного виховання і утримання дитини, хоча і можливі певні труднощі, які можна подолати - 
3. Матейчек, T. Гурко (Z. Mateychek, T. Gurko) [14]. Тобто мають місце не девіантні форми батьківства, а специфічні.

Ми згодні з твердженнями вчених, що сучасні форми шлюбу і сім'ї відповідають історичній логіці демографічного розвитку та сучасному типу відтворення населення (С. Захаров, А. Вишневський (S. Zakharov, A. Vishnevsky)). Шлюбно-сімейна поведінка населення формується під впливом сучасних принципів розвитку суспільства - індивідуалізації, емансипації, свободи вибору. Проте треба визнати неоднозначність змін у матримоніальній та репродуктивній поведінці населення, складність передбачення віддалених наслідків цих змін, існування певних протиріч між інтересами людства, держави і особистості саме в демографічній сфері. Потрібно визнати існування певних протиріч між новою формою шлюбних відносин (відхід від моделі шлюбу на все життя, плюралізація форм шлюбу) і потребою суспільства у комфортних умовах соціалізації підростаючого покоління, які забезпечує традиційний інститут батьківства. Повна сім'я, в якій дитину утримують та виховують батько і мати, $€$ найбільш комфортною для дитини, вона забезпечує захищеність її розвитку, засвоєння моделі поведінки, норм і правил відповідно до своєї статі та відносно осіб іншої статі. Можна припустити, що зараз має місце нерівномірний розвиток інститутів (у даному випадку інститутів шлюбу і батьківства), який вчені пов'язують із різним часовим циклом інститутів, що призводить до виникнення інституційних конфліктів [2, С. 29].

Розв'язання цього конфлікту потребує не повернення до старих форм шлюбносімейної поведінки, що неможливо, а модернізації інституту батьківства на сучасних гуманістичних принципах поваги і любові до кожної дитини, розуміння іiі цінності, відповідального ставлення до батьківських обов'язків в якій би формі шлюбних стосунків не перебувала та чи інша особа. Ця нова якість батьківства одержала назву «відповідального батьківства» чи «нового батьківства». Сучасне відповідальне батьківство грунтується на самореалізації особистості у виконанні батьківських функцій, тому може «виходити за біологічні межі», тобто бути не пов'язане зі шлюбом та біологічними (кровно-родинними) відносинами: всиновлення дитини, батьківство з використанням деяких репродуктивних технологій (донорства статевих клітин, сурогатного материнства) - ці форми батьківства іноді визначають як «соціальне батьківство». Сучасне відповідальне батьківство характеризується свідомим ставленням до появи дитини та іiі виховання, партнерськими стосунками між батьками та між батьками і дітьми, гнучким підходом до гендерних ролей у родині [15, C. 1-29]. Не зупиняючись докладно на трансформації гендерних ролей у сучасному батьківстві (це окреме велике питання), не можна не звернути увагу на появу моделі «нового» батька, відповідального та турботливого, чиї обов'язки не зводяться до ролі годувальника родини, а полягають у діяльності з організації побуту дитини та іiі виховання [16].

Розвиток сім'ї та батьківства в України відбувається відповідно до цивілізаційних закономірностей, однак, як і в кожній країні, він має національні особливості. Складність сучасного етапу розвитку українського суспільства, економічна криза, невирішеність багатьох соціально-економічних проблем ускладнюють життєдіяльність і розвиток сім'ї, створюють негативні умови для реалізації функцій батьківства, продукують низку негативних тенденцій та явищ.

В Україні, як і в інших країнах Європи, на початку XXI століття спостерігається плюралізація форм сім'ї та батьківства, однак більшість сімей з дітьми залишається традиційними: у 80 \% сімей діти мешкають з обома батьками, майже 80 \% дітей (у 
2014 р. 78,9 \%) народжується у батьків, які перебувають у зареєстрованому шлюбі. Водночас у кожному п’ятому домогосподарстві, де є діти, вони мешкають без одного чи обох батьків (98 \% цих домогосподарств - це однобатьківські сім’ї, у 2 \% діти мешкають з родичами чи іншими особами). За нашими оцінками, майже кожна десята сім'я з дітьми (8-10\%) - реструктурована, тобто внаслідок повторного шлюбу дітей виховує вітчим чи мачуха $[17$, С. $85 ; 18$, С. 8$]$.

Недостатнє економічне забезпечення відтворення населення сучасної України, несприятливе соціально-економічне середовище для поєднання членами сім'ї професійної діяльності й батьківських обов'язків впливають на систему відносин батьки-діти, деформуючи специфіку батьківства у різних типах сім’ї, посилюючи негативні моменти та збільшуючи ризики. Так, вибіркові дослідження сільських дітей вказують на значну їх залученість до домашньої та сільськогосподарської праці, однак це обумовлено як специфікою сільського життя, так і матеріальними проблемами сімей. Хоча раннє залучення до колективної сімейної праці експерти оцінюють позитивно, однак через малозабезпеченість сімей досить часто інтенсивність цього залучення переходить ту межу, за якою починається порушення гармонійного розвитку дитини (праця заважає навчанню в школі, негативно впливає на успішність тощо) [19, С. 119-126].

Щодо багатодітних сімей, то в умовах сучасної України організаційна, психологічна, емоційна специфіка батьківства у багатодітних сім'ях відходить на другий план через гостроту проблем грошового та житлового забезпечення багатодітних. Традиції багатодітності наша країна втратила давно: за переписом населення 1970 року лише в 13,1 \% сімей з дітьми виховувалось троє і більше дітей, 1979 р. - 8,7 \%, 1989 р. - 8,4 \%, 2001 р. - 5,7 \%. Однак на початку 2014 р. в Україні проживало 323575 багатодітних сімей, у них - 1090401 дітей. У 2015 р., за даними вибіркових досліджень, у 3 \% домогосподарств із дітьми мешкало троє і більше дітей. Дослідники констатують високий ризик бідності і навіть злиденності багатодітних сімей: ризик бідності зростає вже з появою другої дитини в сім’і, і значно посилюється, якщо в сім’ї троє і більше дітей. Ці сім’ї часто обмежені у можливостях повноцінного харчування дітей, придбання товарів та послуг для розвитку дітей, мають незадовільні житлові умови [20, С. 7-16].

Більшість дітей в Україні мешкає в нуклеарній сім’ї; складні сім’ї, де разом проживають кілька шлюбних пар, не є поширеними, однак досить часто зі шлюбною парою проживає один із прабатьків чи інший родич. За нашими оцінками, приблизно $20 \%$ дітей проживає в сім’ї разом із дідусем чи бабусею (чи обома). Специфікою України є те, що і в умовах нуклеарізації сімей значення прабатьків для організації життєдіяльності й виховання онуків залишається досить суттєвим. Бабуся і дідусь формують ту сімейну атмосферу любові і турботи, яку не завжди можуть забезпечити батьки, зайняті професійною діяльністю. Види допомоги представників старшого покоління поступового змінюються, залежать від форми проживання (разом із онуками чи окремо, на якій відстані), однак обстеження свідчать, що більшість літніх жінок і чоловіків, які мають онуків, допомагають їх виховувати й утримувати [21, С. 129-131].

Несприятливі економічні умови життєдіяльності сімей в Україні посилюють ризики однобатьківських сімей, у першу чергу ризик бідності. Вибіркові дослідження засвідчують економічні та морально-психологічні проблеми, які існують у цих сім'ях: у порівнянні з іншими сім'ями з дітьми в них частіше спостерігаються фінансові проблеми, коштів вистачає лише на харчування, члени сім’ї не відчувають себе щасливими; 
проблемою є і відсутність у нашій країні традиції участі батька, який не проживає з дитиною, у іiі вихованні [17, С. 86-88, 93-94, 154-155]. Щодо реструктурованих сімей, то специфіка батьківства в них в умовах України ще потребує дослідження. У цих сім'ях існує ризик психологічного, емоційного напруження, непорозуміння між дитиною і вітчимом/мачухою, можливі конфлікти. Ці сім’ї потребують психологічної та педагогічної підтримки, порад відповідних спеціалістів, однак в Україні не поширена практика користування послугами сімейних психологів та аналітиків, значна частина батьків мало обізнані у проблемах дитячої психології та педагогіки, що посилює відповідні ризики.

Україна є однією з найбільших країн-донорів робочої сили в Європі, і внаслідок трудової міграції в країні з’явились сім'ї, члени яких мешкають у різних країнах. Цей тип сім’ї одержав назву транснаціональної, і якщо в такій сім’ї є дитина, то або в умовах дистанційного шлюбу дитина мешкає з одним із батьків (за даними обстежень, більше половини зовнішніх мігрантів перебувають у шлюбі), або, якщо за кордоном працює мати, яка сама виховує дитину (28 \% жінок-мігрантів є розлученими чи вдовими), то дитина мешкає в сім'ї родичів. У таких сім'ях реалізація батьківських функцій деформована, відбувається спілкування і виховання «на відстані» через сучасні засоби зв'язку, що не є повноцінним, батьки віддаляються від реальних проблем своїх дітей [22]. Негативні наслідки цієї форми батьківства підсилює нелегальний характер значної частини міграції, що, разом із фінансовими проблемами, зменшує можливості періодичного безпосереднього спілкування батьків і дітей (під час відпусток, канікул, свят тощо).

Низький життєвий рівень населення, поширення безробіття на фоні значного майнового і соціального розшарування населення стали причиною формування прошарку соціопатичних сімей, які не виконують свої обов’язки з утримання та виховання дітей через безвідповідальність, зловживання алкоголем, наркоманію, насильство, застійне безробіття. Батьки в цих сім'ях ухиляються від виконання своїх обов’язків, тобто не піклуються про фізичний і духовний розвиток дитини, їі навчання, не забезпечують необхідного харчування, медичного догляду, лікування дитини. Це серйозне свідчення погіршення якості населення, розбалансованості інституціонального середовища через неузгодженість функцій сім’ї та інших суспільних інститутів.

В останні роки державі вдавалось активізувати роботу з такими сім'ями соціальних служб, які надавали їм соціально-економічні, психологічні та інформаційні послуги, здійснювали соціальний супровід з метою створення безпечного середовища для дитини. Допомога сім'ям з дітьми, які опинились у кризових ситуаціях, стала дієвим засобом профілактики відторгнення дитини з родини, завдяки чому з $2010 \mathrm{p}$. почалось поступове зменшення в країні чисельності дітей-сиріт та дітей, позбавлених батьківського піклування. Однак військові дії на сході країни у 2014-2015 pр., різке зниження життєвого рівня населення призвели до появи сімей, в яких батькам украй складно виконувати у повній мірі свої функції з утримання і виховання дітей: це сім’і, які мешкають у зоні бойових дій, на окупованих територіях, сім’ї вимушених переселенців. Батьки, які пережили тяжкий стрес через втрату близьких і родичів, звичного соціального середовища, опинились в умовах раптової бідності, не завжди здатні в повній мірі виконувати свої сімейні обов'язки. Це стало головною причиною збільшення у 2014-2015 роки кількості дітей, які мешкають у державних інституційних закладах (дитячих будинках системи МОН України та будинках дитини МОЗ України) за рахунок дітей, які перебувають там за заявою батьків; хоча 
протягом попередніх десяти роки відбувався позитивний процес зменшення їхньої чисельності у цих закладах.

Висновки. Наслідком сучасних трансформацій інститутів сім’ї та шлюбу, різноманіття типів і форм сімейних об'єднань стала специфіка батьківства в різних сім'ях, плюралізація його форм. Значна частина дітей виховується у сім'ях, де норми і правила батьківства відрізняються від традиційних - в однобатьківських і реструктурованих сім’ях, транснаціональних сім'ях тощо. Сучасний світ дає людині особисту свободу щодо вибору моделі шлюбно-сімейної поведінки, однак це принципово змінює умови соціалізації дитини, що продукує численні проблеми та ризики. На нашу думку, розв’язання цього протиріччя, тобто створення комфортних умов для життєдіяльності й розвитку дитини зі збереженням принципів свободи особистості щодо вибору стилю життя, можливо лише шляхом модернізації інституту батьківства на засадах свідомого, гуманного і відповідального ставлення до дитини незалежно від форми стосунків ії батьків, розуміння цінності дитини для сім’ї та суспільства, тобто на принципах відповідального батьківства.

Ризики, які продукує плюралізація форм батьківства, в Україні посилюються недостатнім економічним забезпеченням відтворення населення, некомфортним для сімей з дітьми соціально-економічним середовищем, поширенням соціальних патологій алкоголізму, наркоманії, сімейного насильства. Складність сучасного етапу розвитку України, а особливо наслідки зборойного конфлікту на сході країни, потребують оперативних, науково обгрунтованих заходів соціально-демографічної політики. Однак остаточне розв'язання проблем щодо сім'ї та батьківства можливо лише в умовах значного економічного і соціального прогресу українського суспільства.

\section{ЛІТЕРАТУРА}

1. Социология семьи / Под ред. А.И. Антонова. - М. : ИНФРА-М, 2005. - 640 с.

2. Институциональная архитектоника и динамика экономических преобразований / Под ред. А.А. Гриценко. - Харків : Форт, 2008. - 928 с.

3. Шлюб, сім'я та дітородні орієнтації в Україні. - К. : АДЕФ-Україна, 2008. - 256 с.

4. Корман А.О. Сімейні відносини та батьківство. Навчально-методичний посібник. - К. : Міжрег. академія управл. персоналом, 2013. - 195 с.

5. Гурко T.А. Родительство: социологические аспекты. - М. : Центр общечеловеческих ценностей, 2003. - $164 \mathrm{c}$.

6. Nisbet R. The Quest for Community. A Study in the Ethics of Order and Freedom. - San Francisco, California : ICS Press, 1990.

7. Кон И.С. Ребенок и общество (Историко-этнографическая перспектива). - М. : Наука, 1988. - $271 \mathrm{c}$.

8. Демографічна криза в Україні. Проблеми дослідження, витоки, складові, напрями протидії. К. : Інститут економіки НАН України, 2001. - 580 с.

9. Van de Kaa D.J. Europe's Second Demographic Transition // Population Bulletin. (Washington). 1987. -. 42. -1 .

10. Вишневский А.Г. Демографическая революция // Избранные демографические труды. Т. 1. Демографическая теория и демографическая история. - М. : Наука, 2005. - С. 5-207.

11. Le Play F. La reforme social en France. Tours, Mame, 1901, huitième éd. tome II, p. 110

12. Карлсон Аллан. Общество - Семья - Личность: Социальный кризис Америки. Альтернативный социологический подход / Перевод с англ. под ред. проф. А.И. Антонова. - М., 2003. $288 \mathrm{c}$.

13. Elizabeth Thomson and Sara S. McLanahan. Reflections on 'Family Structure and Child Well-Being: Economic Resources vs. Parental Socialization // Social Forces.- 2012. - 91.1. - P. 45-53. - Режим доступу : http://sf.oxfordjournals.org/content/91/1/45.extract 
14. Матейчек 3. Некоторые психологические проблемы воспитания детей в неполной семье // Воспитание детей в неполной семье / пер. с чеш. Хваталовой Л.Н.; общ. ред. Н.М. Ершовой. М. : Прогресс, 1980. - С. 70-98.

15. Bjorneberg U. Parenting in Transition: An Introduction and Summary // European Parents in the 1990s. Contradictions and Comparisons / Ed. by Ulla Bjorneberg. - Transaction Publishers : New Brunswick (U.S.A.) and London (U.K.), 2002. -P. 1-29.

16. Чернова Ж. Семейная политика в западноевропейских странах: модели отцовства // Журнал социологии и социальной антропологии. - 2012. T. - XV, № 1 (60). - С. 103-122.

17. Сім'я та сімейні відносини в Україні: сучасний стан і тенденції розвитку : кол. моногр. / Лібанова Е.М., Аксьонова С.Ю., Слюсар Л.І. та ін. - К. : Основа - Принт, 2009. - 248 с.

18. Показники і соціальний контекст формування здоров'я підлітків (за результатами соціологічного опитування в межах міжнародного проекту ВООЗ «Здоров'я та поведінкові орієнтації учнівської молоді» / Український ін-т соціальних досліджень ім. О.Яременка, Міністерство охорони здоров’я України. - К., 2014. - 158 с.

19. Стан та соціальний захист сільських дітей. Тематична державна доповідь про становище дітей в Україні за підсумками 2004 року. - К. : Державний. ін-т проблем сім’ї та молоді, 2005. - 250 с.

20. Нерівні можливості дітей в Україні: аналіз та рекомендації для політики (на основі моніторингу щодо економічної нерівності домогосподарств та доступу дітей до послуг соціальної сфери). - К. : К.І.С., 2011. - 48 с.

21. Населення України: імперативи демографічного старіння : Кол. моногр. // Лібанова Е.М., Курило І.О., Слюсар Л.І., Аксьонова С.Ю. та інші. - К. : АДЕФ-Україна, 2014. - 288 с.

22. Транснаціональні сім'ї як наслідок української трудової еміграції: проблеми та шляхи їх розв’язання // Зб. доп. Міжнарод. наук.-практ. конф.. - Львів : Вид-во Нац. ун-ту «Львівська політехніка», 2012. - 476 с.

\section{REFERENCES}

1. Antonov, A. (Eds.). (2005). Sociologija sem'i [Sociology of the Family]. Moscow : INFRA-M [in Russian].

2. Gricenko, A. (Eds). (2008). Institucional'naja arhitektonika i dinamika jekonomicheskih preobrazovanij [Institutional architectonic and dynamics of economic transformation]. Kharkiv : Fort [in Russian].

3. Shlyub, sim" ya ta ditorodni oriyentatsiyi v Ukraine [Marriage, childbearing and family orientation in Ukraine] (2008). Kyiv : ADEF-Ukraine [in Ukrainian].

4. Korman, A.O. (2013). Simeyni vidnosyny ta bat'kivstvo [Family relationships and parenting]. Kyiv : Mizhreh. akademiya upravl. personalom [in Ukrainian].

5. Gurko, T.A. (2003). Roditel'stvo: sociologicheskie aspekty [Parenting: Sociological Aspects]. Moscow : Centr obshhechelovecheskih cennostej [in Russian].

6. Nisbet, R. (1990). The Quest for Community. A Study in the Ethics of Order and Freedom. San Francisco, California : ICS Press [in English].

7. Kon, I.S. (1988). Rebenok i obshhestvo (Istoriko-jetnograficheskaja perspektiva) [Children and Society (Historical and ethnographic perspective)]. Moscow : Nauka [in Russian].

8. Demohrafichna kryza v Ukrayini. Problemy doslidzhennya, vytoky, skladovi, napryamy protydiyi [The demographic crisis in Ukraine. Problems studies the origins, ingredients, directions counter] (2001). Kyiv : Institute of Economy NAN Ukraine [in Ukrainian].

9. Van de Kaa, D.J. (1987). Europe's Second Demographic Transition. Population Bulletin. Washington, Vol. 42, 1. [in English]

10. Vishnevs'kij, A.G. (2005). Demograficheskaja revoljucija [The demographic revolution] Izbrannye demograficheskie trudy. Demograficheskaja teorija i demograficheskaja istorija - Selected demographic works. Demographic theory and demographic history, Vol. 1, 5-207. Moscow: Nauka [in Russian].

11. Le Play, F. (1901). La reforme social en France [The social reform in France]. Tours: Mame, huitième éd. [in French].

12. Carlson, A. (2003). Obshhestvo - Sem'ja - Lichnost' : Social'nyj krizis Ameriki. Al'ternativnyj sociologicheskij podhod [Society - Family - Personality : Social crisis America. An alternative sociological approach]. A.I. Antonov (Ed.). Moscow [in Russian]. 
13. Thomson, E. \& McLanahan, S.S. (2012). Reflections on 'Family Structure and Child Well-Being: Economic Resources vs. Parental Socialization, Social Forces, 91, 1, 45-53. (n.d.). sf.oxfordjournals.org. Retrieved from http://sf.oxfordjournals.org/content/91/1/45 [in English].

14. Matejchek, Z. (1980). Nekotorye psihologicheskie problemy vospitanija detej v nepolnoj sem'e [Some psychological problems of education of children in single-parent family]. Vospitanie detej v nepolnoj sem'e - Children in single-parent family. L.N. Hvatalovoj (Ed.). Moscow : Progress [in Russian].

15. Bjorneberg, U. (2002). Parenting in Transition: An Introduction and Summary. European Parents in the 1990s. Contradictions and Comparisons. U. Bjorneberg (Ed.). Transaction Publishers : New Brunswick (U.S.A.) and London (U.K.) [in English].

16. Chernova, Zh. (2012). Semejnaja politika v zapadnoevropejskih stranah: modeli otcovstva [Family policy in Western Europe: a model of fatherhood]. Zhurnal sociologii i social'noj antropologii - The Journal of Sociology and Social Anthropology , XV, 1 (60), 103-122 [in Russian].

17. Sim"ya ta simeyni vidnosyny v Ukrayini: suchasnyy stan i tendentsiyi rozvytku [Family and family relations in Ukraine: current situation and trends] (2009). Kyiv : Osnova - Prynt [in Ukrainian].

18. Pokaznyky i sotsialnyi kontekst formuvannia zdorov'ia pidlitkiv.(za rezultatamy sotsiolohichnoho opytuvannia v mezhakh mizhnarodnoho proektu VOOZ «Zdorov'ia ta povedinkovi oriientatsii uchnivskoi molodi» [Indicators and social context of adolescent health. (According to the poll within the international WHO project «Health and Behavioral orientation of students'»] (2014). Kyiv : Ukrainian Institute of Social Research of Ministry of Health of Ukraine [in Ukrainian].

19. Stan ta sotsial'nyy zakhyst sil's'kykh ditey. Tematychna derzhavna dopovid' pro stanovyshche ditey v Ukrayini za pidsumkamy 2004 roku [Status and Social Protection of rural children. Thematic government report on the situation of children in Ukraine in 2004] (2005). Kyiv : The State Institute of Family and Youth [in Ukrainian].

20. Nerivni mozhlyvosti ditey v Ukrayini: analiz ta rekomendatsiyi dlya polityky (na osnovi monitorynhu shchodo ekonomichnoyi nerivnosti domohospodarstv ta dostupu ditey do posluh sotsial'noyi sfery) [Unequal opportunities of children in Ukraine: Analysis and Recommendations for Policy (based on the monitoring of economic inequality of household and children's access to social services)] (2011). Kyiv : K.I.S. [in Ukrainian].

21. Naselennya Ukrayiny: imperatyvy demohrafichnoho starinnya [The population of Ukraine: the imperatives of demographic aging]. (2014). Kyiv : ADEF-Ukrayina [in Ukrainian].

22. Transnatsionalni sim'i yak naslidok ukrainskoi trudovoi emihratsii: problemy ta shliakhy yikh rozv'iazannia [Transnational families as a result of Ukrainian labor migration: problems and solutions]. (2012). Zbirnyk dopovidey Mizhnarodnoyi naukovo-praktychnoyi konferentsiyi - Collection of International Scientific Conference. L'viv : NU L'vivs'ka politekhnika [in Ukrainian].

Стаття надійшла до редакції журналу 11.04.2016. 